\title{
AERODYNAMIC RESISTANCE OF A BIOFILTER WITH A PACKING OF PINE CONES
}

\author{
Aleksandr MITIN, Natalya NIKOLAJKINA, Aleksandr PUSHNOV \\ Engineering Ecology of Municipal Services, Moscow State University of Mechanical Engineering, \\ 38 Bolshaya Semenovskaya str., 107023 Moscow, Russia
}

Submitted 06 May 2014; accepted 16 Jan. 2015

\begin{abstract}
The results of experiments on practical suitability of a biofilter packing made of natural materials - pine cones are provided. Geometric characteristics of a random packing of pine cones are calculated and compared with other types of packings of artificial and natural materials. Aerodynamic tests of the packing are carried out and obtained data are compared with the data for other packings. Some recommendations on improving the performance characteristics of the packing are suggested.
\end{abstract}

Keywords: biofilter, aerodynamic resistance, pressure drop, random packing, pine cone.

\section{Introduction}

At the present stage of the technological progress, the issue of preserving vital elements such as air becomes urgent. Although the problem is recognized, industrial companies reluctantly accede to installation of effective air purification systems. Therefore, a low cost is one of the most important requirements to such systems. One of the effective and inexpensive methods is biological air purification (Baltrenas et al. 2004a, 2004b; Pushnov et al. 2012). Volatile organic compounds (VOC) such as methanol, phenol, formaldehyde, butanol, toluene, benzene as well as other not less harmful compounds like, for example, ammonia and hydrogen sulphide ejected into the atmosphere by food, chemical, woodworking and agricultural enterprises unrecoverably cripple our ecology (Baltrenas, Vaiskunaite 2004; Sharvelle et al. 2008; Zagorskis 2009). Using standard air purification systems such as absorption, adsorption or incineration is expensive in comparison to the biological method (Veprickiy et al. 2012). The biological air purification method is an attractive alternative for low concentration air streams due to its low energy consumption, relatively moderate operating costs and minimum by-products production (Kumar et al. 2011). The advantage of the biological air purification method is the technological effectiveness of the process. Within this process, no secondary waste is produced. Biological air purification is performed through oxidation of organic compounds by microorganisms up to the extraction of carbon dioxide and water vapours to maintain their vital activity (Mitin et al. 2012).
However, what complicates the use of a biofilter is dependence of its efficiency on the conditions created for the microorganism's activity. Water, nutrients and energy supply (carbon) are necessary to keep this activity normal.

The efficiency of the biofilter depends on the properties of the packing since it serves as a platform for the biofilm. In this connection, the packing is a major structural element working in the biofilter. Packings are classified according to the material they are composed of: organic (sawdust, pine cones, bark, compost etc.) and synthetic (plastic, ceramic, polyurethane foam, etc.), as well as organic ones without nutrients (lava rock, perlite, etc.); by the method of stacking (random, structured, combined), and so forth. As the experience of biofilter usage shows, the most suitable type is an organic packing with nutrients.

In addition to nutrients, there are other essential characteristics such as water content, bed porosity, specific surface area, organic matter, etc. Table 1 shows the main working parameters of organic packing (Chen, Hoff 2009) as well as the pine cones packing proposed here.

The choice of the packing type (structured or random) as well as packing material (inert or natural) is a complex technology solution (Devinny et al. 1999).

Inert packing is commonly used in biotrickling filters. Such filling is distinguished for its good mechanical properties, low weight and chemical stability. Moreover, it satisfies all the necessary requirements for the microorganisms' activity.

Corresponding author: Aleksandr Mitin

E-mail: mitin.rus@gmail.com 
Table 1. Initial characteristics of biofilters and organic packing materials

\begin{tabular}{|c|c|c|c|}
\hline Parameter & $\begin{array}{l}\text { Coconut } \\
\text { fiber }\end{array}$ & Compost & Pine cones \\
\hline Water content $(\%)$ & $78 \pm 2$ & $46 \pm 0$ & $70 \pm 3$ \\
\hline $\begin{array}{l}\text { Organic matter (\% } \\
\text { dry weight) }\end{array}$ & $81 \pm 2$ & $38 \pm 5$ & $87 \pm 1$ \\
\hline Bed porosity & 0.55 & 0.43 & 0.8 \\
\hline C (\% dry weight) & $47.32 \pm 0.12$ & $28.65 \pm 1.51$ & $49.00 \pm 0.60$ \\
\hline H (\% dry weight) & $5.69 \pm 0.12$ & $3.29 \pm 0.21$ & $\begin{array}{c}\text { Not } \\
\text { analyzed }\end{array}$ \\
\hline $\mathrm{N}$ (\% dry weight) & $0.52 \pm 0.01$ & $2.87 \pm 0.33$ & $0.57 \pm 0.01$ \\
\hline S (\% dry weight) & $\begin{array}{c}\text { Not } \\
\text { detected } \\
\end{array}$ & $0.52 \pm 0.01$ & $\begin{array}{c}\text { Not } \\
\text { analyzed }\end{array}$ \\
\hline P (\% dry weight) & 0.23 & Not analyzed & $\begin{array}{c}\text { Not } \\
\text { analyzed }\end{array}$ \\
\hline $\begin{array}{l}\text { Specific surface area } \\
\left(\mathrm{m}^{2} / \mathrm{g}\right)\end{array}$ & $0.75 \pm 0.10$ & $5.12 \pm 0.10$ & $2 \pm 0.10$ \\
\hline
\end{tabular}

Lava rock, plastic rings, activated carbon, ceramics rings, polyurethane foams and perlite are the most popular packing materials (Vedova 2008; Ryu et al. 2010). Inert packings have the following disadvantages: the necessity to be inoculated by biomass, absence of nutrients, low wettability, low absorption and small specific surface area.

The amount of organic compounds in refined air is not always sufficient to maintain the microbiological activity in the biofilter. Thus, using a packing composed of natural materials contained in carbon could solve this problem.

The obstruction issue presents much more complications in biotrickling filters than in conventional biofilters (Vedova 2008). Due to unconfined growth of biomass, space is reduced so that the pressure drop is changed in the reactor. Therefore, the following requirements are imposed on biofilter packings: high specific surface, porosity and low aerodynamic resistance.

Pine cones were considered as a random packing for heat mass exchange processes in biofilters by the Moscow State University of Mechanical Engineering in the Environmental and Chemical Engineering Institute. Pine cones are a natural packing material saturated with carbon which positively affects the activity of the microorganisms. Moreover, a pine cone has a high specific surface area as well as an aerodynamically streamline form.

\section{Methodology}

Many studies devoted to the biofiltration process discuss packings of natural materials such as sawdust, bark, wood chips, and others (Dorado et al. 2010). Such natural materials are an additional source of substrate for microorganisms. The porous structure, high absorption, and wettability make these materials promising to be used as biofilter packing. From the viewpoint of hydrodynamics, however, all of the above mentioned types of packings have a high aerodynamic resistance (Chen, Hoff 2009) that increases the overall power consumption. Overcoming of the additional resistance is achieved through increasing the fan speed, which affects the increase of electricity consumption. The following experiments on the estimation and comparison of pressure drop figures between different types of packings were carried out.

These experiments were carried out in compliance with the Russian Federal Standards (hereinafter - FS):

- FS 17.2.4.07-90: Environment protection. Atmosphere. Methods for determination of pressure and temperature of gas-and-dust streams from stationary sources of pollution (year 2013);

- FS 17.2.4.06-90: Nature protection. Atmosphere. Methods for determination of velocity and flow rate of gas-and-dust streams from stationary sources of pollution (year 2013).

\subsection{Experimental setup}

The experiments were carried out on a stand; the corresponding scheme is presented in Figure 1. The general view of the installation is presented in Figure 2.

The installation consists of a packing column (1) with packing (2), air blower (3), rate-of-flow meter (4),

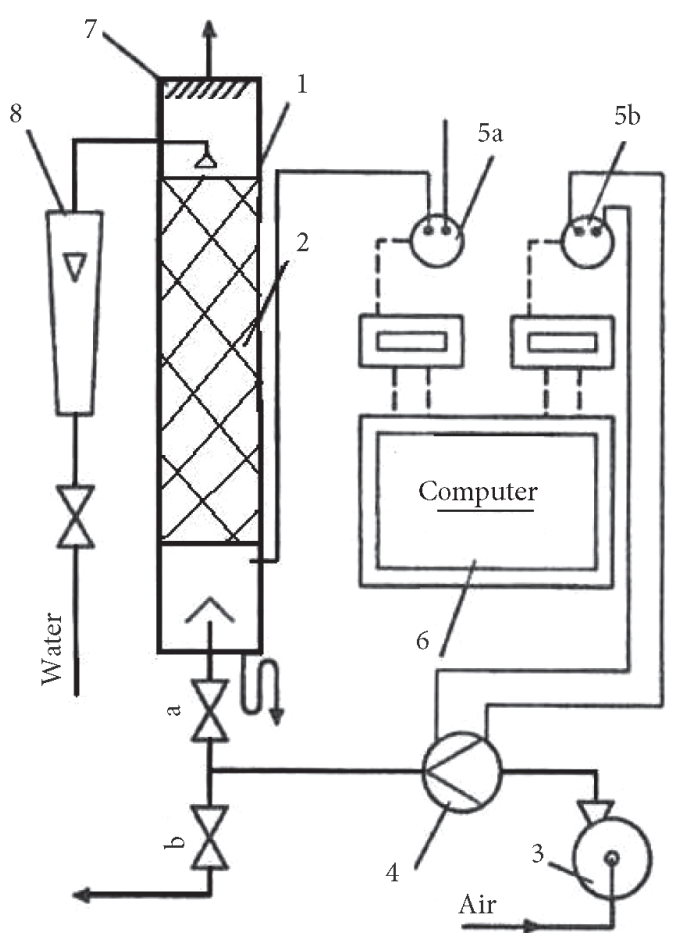

Fig. 1 . The circuit of the experimental device: 1 - column; 2 - pine cones; 3 - ventilator; 4 - rate-of-flow meter; 5 - differential pressure gage; 6 - computer; 7 - mist eliminator; 8 - rotameter 


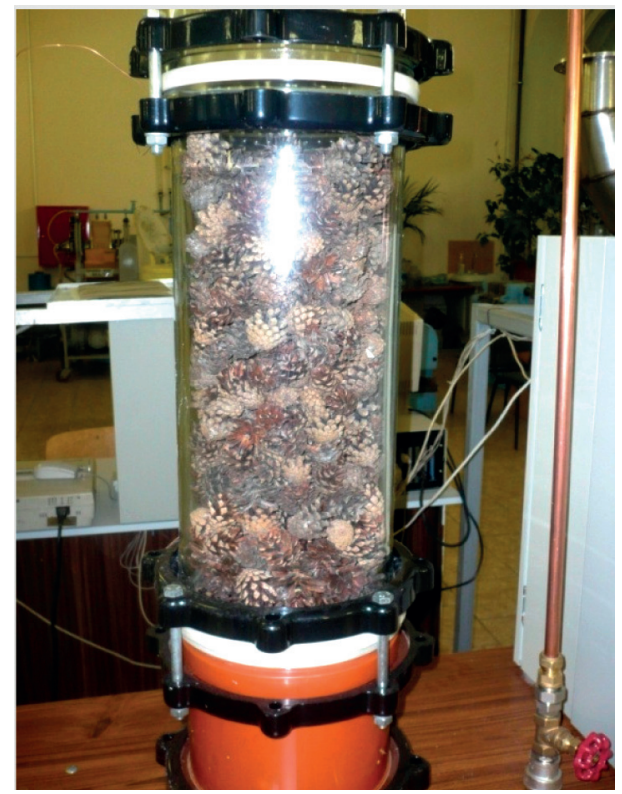

Fig. 2. Installation general view

rotameter (8), systems of air gates $(a, b)$, differential pressure gage $(5 a, 5 b)$ and the serving computer $(6)$. The computer transforms the experiment results and presents them in a digital and graphic form showing the dependence of hydraulic resistance of the packing on the speed of air in the column. Air volatilizes through the mist eliminator (7).

Air moves in the column through the rate-of-flow meter. The valve regulates the air supply. Water consumption for irrigation purposes in the column is defined by the rotameter. The differential manometers measure the pressure difference in the column and the air consumption.

The experiments for determination of the pressure drop are carried out in a countercurrent column. Initially, the experiments are conducted to determine the pressure drop when the packing is dry. The packing is randomly filled in.

There was no risk of damaging the packing while filling it randomly due to the natural structure of pine cones.

The column diameter is $200 \mathrm{~mm}$, the column height is $1000 \mathrm{~mm}$, the packing height is $800 \mathrm{~mm}$. The air flow reaches at $200 \mathrm{~m}^{3} / \mathrm{h}$ which corresponds to the velocity flow $\mathrm{W}_{0}=0-1 \mathrm{~m} / \mathrm{s}$ in the calculation of the total cross section empty apparatus. The air temperature is $20^{\circ} \mathrm{C}$, the barometric pressure is $101.3 \mathrm{kPa}$.

\subsection{Equipment used in the experiment}

The following equipment was used for the experiments:

- Manometer type MCM-2400(5)-1.0 meeting the technical standards of accuracy class 1.0;

- Liquid manometers, U-shaped in accordance with FS 9933;

- Gauges showing, accuracy class 1.5;

- Pressure tube designed by NIIOGAZ FS 17.2.4.06;
- Ethyl alcohol in accordance with FS 17299;

- Technical glass thermometer according to FS 28498;

- Barometer accuracy class 1.0.

All used equipment complies with the Russian Federal Standards:

FS 17.2.4.06-90: Nature protection Atmosphere Methods for determination of velocity and flow rate of gas-and-dust streams from stationary sources of pollution (actualization 2013 year).

FS 17.2.4.07-90: Environment protection. Atmosphere. Methods for determination of pressure and temperature of gas-and-dust streams from stationary sources of pollution (actualization 2013 year).

\subsection{Description of the packing under test}

The right choice of a packing material used in a biofilter is an important decision for achieving high efficiency of the process and maintaining high output capacity for a longterm period.

The main function of the packing is to provide contact of the gas and liquid phases with the biofilm on the packing surface. The packing also performs some other functions: equal distribution of both gas and liquid phases, ensuring a minimal drop pressure, circulation of the nutrients, and self-purification ability (i.e. withdrawal of excessive biomass) (Dumont et al. 2008).

Packing materials that can be used in biofiltration of volatile organic compounds are grouped into two main categories: organic and inorganic. The latter can be classified as natural inorganic materials or entirely synthetic materials.

Organic materials are commonly considered by many authors as preferred materials for the biofiltration process. Such materials usually include peat, soil and compost. However, wood bark, sugarcane bagasse and peanut shells are also used. The main advantage of the mentioned materials is that they are available for use and naturally contain contaminant-degrading microorganisms (no cultivation by microorganisms is required). Another advantage is that they provide nutrients such as nitrogen and phosphorous necessary for the microorganisms' activity. However, such materials become compressed with time, increasing the drop pressure and thus decreasing the efficiency of the biofilter. They have a low specific surface area and need to be replaced after 2-5 years, being difficult to regenerate (Delhomenie, Heitz 2005).

Natural materials with random filling are commonly used as packing in traditional biofilters. Natural packings include peat, brushwood and peat mix, compost, wood bark, straw, sawdust, soil, etc. (Devinny et al. 1999; Baltrenas, Zagorskis 2010).

Compost is rich with nutrients and microorganisms fertilizer. Due to the fact that compost is the most 
nourishing environment for microorganisms, no additional nutrients are required for their activity. Besides, using compost helps to get rid of accumulating waste. As a biofilter packing material performing air purification purposes, compost can be used in high concentration.

However, using such materials as packing results in the increase of overall sizes of the biofilter (for example, traditional open biofilters). Such biofilters are devoid of any mobility and cannot be established and used directly in shops due to technical reasons.

Other types of filling include bark, chips, pine bark (Vaiskunaite 2004). Such filling has the following properties: high porosity and water retention, low absorption, enough content of nutrients for the microorganisms' activity, free access of air. Also, these natural materials are rather durable when used as filling in the biofilter. The service life of such packing is within the range of 1-3 years (Pushnov et al. 2012). However, filling of this type is not efficient in terms of operation. It has a high hydraulic resistance and has to stay pressed for a long time. This negatively affects the efficiency of the apparatus.

Pine cones (see Fig. 3) were collected in a forest and then washed and dried in an oven until virtually complete absence of moisture. After that, they were randomly loaded into the laboratory apparatus depicted in Figure 2.

The average size of the cones varied in a range of 40 to $70 \mathrm{~mm}$ in height and 30 to $50 \mathrm{~mm}$ in width.

The aim of this work was to determine the pressure drop of pine cones in dry mode. After receiving the results, further work will be continued to explore the possibility of using pine cones as a packing for biofilters.

Pine cones were considered by our University as one of the possible types of filling in the biofilter. This packing has all the above mentioned positive features which are inherent in packings of natural materials. Its most important feature is that it has a high specific surface and low pressure drop. This peculiarity distinguishes it from other packings of this type. A comparison of the characteristics

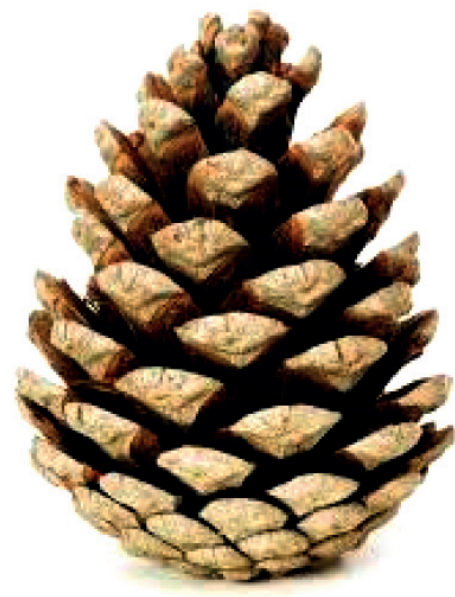

Fig. 3. Pine cones packing of the pine cones packing to those of other packings is presented below in the form of tables and graphs of geometric characteristics of the pressure drop in the packing.

\subsection{Geometric characteristics of the packing}

Table 2 shows the geometric characteristics of the random filling of pine cones. These characteristics were obtained by various methods described below.

Table 2. Geometric characteristics of the pine cones packing

\begin{tabular}{lccc}
\hline Packing type & $\begin{array}{c}\text { Specific } \\
\text { surface }(a), \\
\mathrm{m}^{2} / \mathrm{m}^{3}\end{array}$ & $\begin{array}{c}\text { Void } \\
\text { fraction }(\varepsilon), \\
\mathrm{m}^{3} / \mathrm{m}^{3}\end{array}$ & $\begin{array}{c}\text { Equivalent } \\
\text { diameter }\left(d_{e}\right), \\
\mathrm{m}\end{array}$ \\
\hline Pine cones & 320 & 0.8 & 0.010 \\
\hline
\end{tabular}

The most important geometric characteristics of the packing are the following: the linear size which depends on the packing shape, void fraction $\left(\varepsilon, \mathrm{m}^{3} / \mathrm{m}^{3}\right)$ and surface area $\left(\mathrm{a}, \mathrm{m}^{2} / \mathrm{m}^{3}\right)$. The last two parameters present another important indicator - equivalent diameter which can be determined by the following formula (1):

$$
d_{e}=4 \varepsilon / a
$$

where: $d_{e}$ - equivalent diameter, $\mathrm{m} ; \varepsilon$ - void fraction, $\mathrm{m}^{3} / \mathrm{m}^{3} ; a-$ specific surface, $\mathrm{m}^{2} / \mathrm{m}^{3}$.

Roughness of the packing surface is also an important factor. It affects the properties of the packing in the following way: high roughness slightly increases the free volume, as well as hydraulic resistance, and reduces bulk density of the packing. High roughness also furthers strengthening of the biofilm on the packing surface. Packing roughness values can be calculated in the same way as roughness of tube surface (Kagan et al. 2013).

Porosity or the share of the void fraction can be determined by filling up the volume of the packing by water. Therefore, porosity $\left(\varepsilon, \mathrm{m}^{3} / \mathrm{m}^{3}\right)$ is evaluated by the relation of the volume of water to the volume of packing (Pushnov, Kagan 2011). Free cross-section $\left(S_{\text {free }}, \mathrm{m}^{2} / \mathrm{m}^{2}\right)$ is also an important feature. Usually it equals the free volume of the packing: $V_{f r}=S_{f r}$.

The free volume share (or average porosity of the packing) is an important statistical characteristic required for the thermal and hydrodynamic calculations applied to packed devices. Numerically, the free volume of the packing equals the free cross-section volume of the packing. The free volume of the packing equals the volume of the packing in the apparatus minus the volume of the packing, $V_{p a c}$ :

$$
\begin{aligned}
& \varepsilon=V_{f r} / V_{l}=S_{f r} / S=\left(V_{l}-V_{p a c}\right) / V_{l}= \\
& 1-\left(\rho_{p a c} / \rho_{m}\right),
\end{aligned}
$$

where: $\varepsilon$ - void fraction, $\mathrm{m}^{3} / \mathrm{m}^{3} ; V_{f r}$ - free volume of layer, $\mathrm{m}^{3} ; V_{1}$ - total volume of layer, $\mathrm{m}^{3} ; S_{f r}$ - clear opening of 
packing, $\mathrm{m}^{2} ; S$ - specific surface, $\mathrm{m}^{2} / \mathrm{m}^{3} ; V_{\text {pac }}$ - volume of packing, $\mathrm{m}^{3} ; \rho_{\text {pac }}$ - poured density, $\mathrm{kg} / \mathrm{m}^{3} ; \rho_{m}$ - density of the packing material, $\mathrm{kg} / \mathrm{m}^{3}$.

The packing specific surface value is calculated depending on the geometric features of the packing: the form of a pine cone is considered as a cone with further adjustment to inaccuracy of the form. The calculations are updated due to the regularities of random packings published in the study (Pushnov, Kagan 2011).

The specific surface of the unirrigated layer of the packing $\left(\mathrm{a}, \mathrm{m}^{2} / \mathrm{m}^{3}\right)$ can be calculated by Formula (3). The pressure drop of the dry layer of the packing should be known $\left(\Delta \mathrm{P}_{\mathrm{c}}, \mathrm{Pa}\right)$, then:

$$
\begin{aligned}
& a=\left(324 \cdot 10^{-6} \cdot \frac{W_{0}^{2}}{v_{g}^{2}}+\frac{0.04 \varepsilon^{2} \cdot \Delta P_{c}}{v_{g} \cdot H \cdot \rho_{g} \cdot W_{0}}\right)^{0.5}- \\
& 18 \cdot 10^{-3} \cdot \frac{W_{0}}{v_{g}},
\end{aligned}
$$

where: $a$ - specific surface, $\mathrm{m}^{2} / \mathrm{m}^{3} ; W_{0}-$ gas velocity per full cross-section of empty apparatus, $\mathrm{m} / \mathrm{s} ; \mathrm{v}_{\mathrm{g}}$ - kinematic coefficient of viscosity, $\mathrm{m}^{2} / \mathrm{s} ; \varepsilon$ - void fraction, $\mathrm{m}^{3} / \mathrm{m}^{3} ; \rho_{g}-$ gas density, $\mathrm{kg} / \mathrm{m}^{3} ; \Delta P_{c}$ - pressure drop on the dry packing, $\mathrm{Pa} ; H$ - height of the layer, $\mathrm{m}$.

The pressure drop of the dry layer $\left(\Delta \mathrm{P}_{\mathfrak{c}}, \mathrm{Pa}\right)$ (necessary for the calculation of a specific surface value) should be determined by the velocity of air corresponding to the frictional regime of the stream (i.e. to the laminar regime). In this case, resistance is given rise only due to the packing surface friction. The laminar regime is defined by the formula:

$$
\operatorname{Re}_{g}=\frac{W_{0} \cdot d_{e}}{v_{g} \cdot \varepsilon} \leq 40,
$$

where: $\mathrm{Re}_{g}$ - equivalent Reynolds number; $W_{0}$ - gas velocity per full cross-section of empty apparatus, $\mathrm{m} / \mathrm{s} ; d_{e}-$ equivalent diameter, $\mathrm{m} ; v_{g}-$ kinematic coefficient of viscosity, $\mathrm{m}^{2} / \mathrm{s} ; \varepsilon$ - void fraction, $\mathrm{m}^{3} / \mathrm{m}^{3}$.

Tables 3 and 4 present the main characteristics of random and structured packings.

Table 2 shows that pine cones have a high specific surface. Their structure provides a very high porosity value, which positively affects the process since the porous structure serves as a convenient rough surface for microorganisms and also satisfies the water needs for the microorganism's activity.

Geometric characteristics of random packings and their comparison are presented in Table 3. As evident from Table 3, a pine cone, a Hackett ring, and a saddle Intaloks (i.e. packings of the same size) have the highest specific surface among a number of random packings. At the same time, it should be noted that, for example, regular filling of Raschig rings can increase the surface area of the packing by $10-18 \%$. However, this regular filling is very sensitive to the uniformity of distribution of the

\begin{tabular}{|c|c|c|c|}
\hline Packing type & $\begin{array}{c}\text { Specific } \\
\text { surface }(a), \\
\mathrm{m}^{2} / \mathrm{m}^{3}\end{array}$ & $\begin{array}{c}\text { Void } \\
\text { fraction }(\varepsilon) \text {, } \\
\mathrm{m}^{3} / \mathrm{m}^{3}\end{array}$ & $\begin{array}{c}\text { Equivalent } \\
\text { diameter }\left(d_{e}\right) \\
\mathrm{m}\end{array}$ \\
\hline $\begin{array}{l}\text { Raschig ring } \\
\text { (ceramic) }\end{array}$ & 110 & 0.735 & 0.0270 \\
\hline $\begin{array}{l}\text { CMR No. } 2 \\
\text { (metal) }\end{array}$ & 150 & 0.95 & 0.0253 \\
\hline $\begin{array}{l}\text { Hiflow ring } \\
\text { (metal) }\end{array}$ & 97.3 & 0.973 & 0.0400 \\
\hline $\begin{array}{l}\text { VSP ring } \\
\text { (metal) }\end{array}$ & 104 & 0.98 & 0.0377 \\
\hline $\begin{array}{l}\text { RMSR ring } \\
\text { (metal) }\end{array}$ & 115 & 0.97 & 0.0337 \\
\hline $\begin{array}{l}\text { Pall ring } \\
\text { (ceramic) }\end{array}$ & 120 & 0.78 & 0.0260 \\
\hline $\begin{array}{l}\text { Hiflow ring } \\
\text { (ceramic) }\end{array}$ & 86.7 & 0.815 & 0.0376 \\
\hline $\begin{array}{l}\text { INTALOX } \\
\text { saddle } \\
\text { (ceramic) }\end{array}$ & 120 & 0.77 & 0.0257 \\
\hline $\begin{array}{l}\text { Pall ring } \\
\text { (plastic) }\end{array}$ & 110 & 0.92 & 0.0334 \\
\hline $\begin{array}{l}\text { Hiflow ring } \\
\text { (plastic) }\end{array}$ & 112 & 0.93 & 0.0332 \\
\hline $\begin{array}{l}\text { NOR-PAC } \\
\text { ring (plastic) }\end{array}$ & 90 & 0.952 & 0.0423 \\
\hline $\begin{array}{l}\text { Hackette } \\
\text { (plastic) }\end{array}$ & 135 & 0.93 & 0.0276 \\
\hline $\begin{array}{l}\text { Envipac } \\
\text { (plastic) }\end{array}$ & 98 & 0.961 & 0.0392 \\
\hline $\begin{array}{l}\text { Pall ring } \\
\text { (plastic) }\end{array}$ & 111 & 0.92 & 0.0100 \\
\hline Flexirings & 65 & 0.94 & 0.0580 \\
\hline Pine cones & 320 & 0.8 & 0.0100 \\
\hline Bark & 250 & 0.5 & 0.0080 \\
\hline
\end{tabular}

Table 3. Geometric characteristics of random packing (the typical size is $50 \mathrm{~mm}$ )

initial liquid phase. Proportional distribution of liquid in the packing is an important requirement since the activity of the microorganisms depends on the timely supply of irrigated liquid (water with nourishing components) (Mitin et al. 2014).

Figure 4 shows the dominant industrial random packings.

Table 4 presents the main industrial structured packings. Random packing compared to structured one, the former has a higher specific surface that positively affects the effectiveness of biological air purification.

Structured packing also has a low pressure drop. The regular structure of the packing allows the film flow regime to be organized contributing to the intensity of the biofiltration process. 


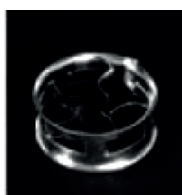

CMR No 2, metal

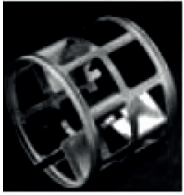

Hiflow ring, metal

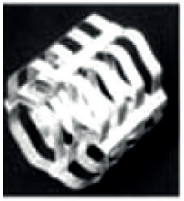

VSP ring, metal

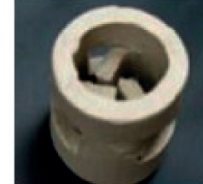

Pall ring, ceramic

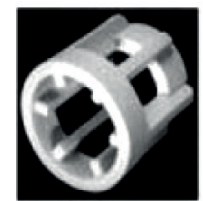

Hiflow ring, ceramic

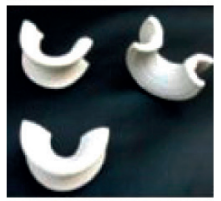

INTALOX saddle, NOR-PAC ring,

ceramic plastic

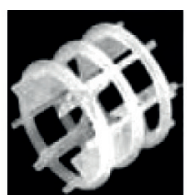

Hiflow ring, plastic

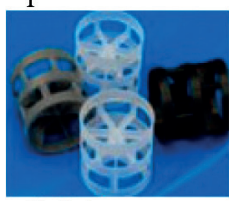

Pallring, plastic

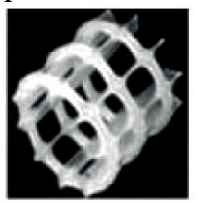

Fig. 4. Forms of the most commonly used industrial random packings

Table 4. Geometric characteristics of structured packing

\begin{tabular}{lccc}
\hline Packing type & $\begin{array}{c}\text { Specific } \\
\text { surface }(a), \\
\mathrm{m}^{2} / \mathrm{m}^{3}\end{array}$ & $\begin{array}{c}\text { Void } \\
\text { fraction }(\varepsilon), \\
\mathrm{m}^{3} / \mathrm{m}^{3}\end{array}$ & $\begin{array}{c}\text { Equivalent } \\
\text { diameter }\left(d_{e}\right), \\
\mathrm{m}\end{array}$ \\
\hline $\begin{array}{l}\text { Mellapak } \\
250 \mathrm{Y} \text { (metal) }\end{array}$ & 250 & 0.96 & 0.01536 \\
\hline $\begin{array}{l}\text { Montz B1-100 } \\
\text { (metal) }\end{array}$ & 300 & 0.93 & 0.01240 \\
\hline $\begin{array}{l}\text { Ralupak 250Y } \\
\text { (metal) }\end{array}$ & 250 & 0.96 & 0.01540 \\
\hline $\begin{array}{l}\text { Euroform } \\
\text { (plastic) }\end{array}$ & 110 & 0.93 & 0.03380 \\
\hline $\begin{array}{l}\text { Sulzer BX } \\
\text { (metal) }\end{array}$ & 500 & 0.90 & 0.00720 \\
\hline $\begin{array}{l}\text { Fi-Pak } \\
\text { (metal) }\end{array}$ & 200 & 0.94 & 0.01880 \\
\hline
\end{tabular}

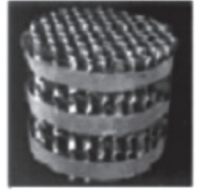

Mellapak 250Y, metal

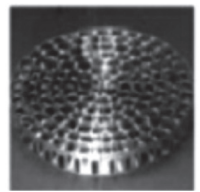

Fi-pak, metal

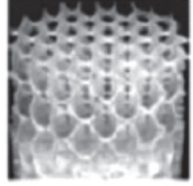

Euroform, plastic

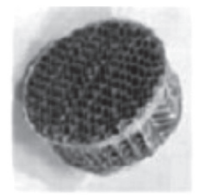

Ralupak 250Y, metal

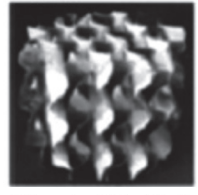

Montz B1-100, metal

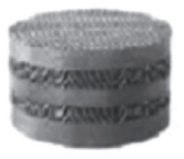

Sulzer, metal
Fig. 5. Typical forms of the most commonly used industrial structured packings
Structured packing is described in more detail in the book (Mackowiak 2010). At present, the major industrial structured packings are used in heat-mass transfer processes but such packings are not widely used in the biofilter process. One of the reasons is that a metal packing material is not really suitable for biofilm formation. On the other hand, the regular structure of the packing could stimulate the breakthrough of gas.

Figure 5 shows the dominant industrial structured packings.

Table 5 illustrates the main properties of packing made of modern and promising materials. Such materials have a high surface area necessary for high performance of the biological air purification process. The highly porous structure of the material (see Table 4) is a convenient surface for biofilm formation. These materials are chemically inert and cannot be ruined by the activity of microbial enzymes.

Table 5. Geometric characteristics of promising packing materials used for biological air purification

\begin{tabular}{lcl}
\hline \multicolumn{1}{c}{ Packing type } & $\begin{array}{c}\text { Specific surface } \\
(a), \mathrm{m}^{2} / \mathrm{m}^{3}\end{array}$ & \multicolumn{1}{c}{ Material } \\
\hline Tri-packs (Jaeger) & 281 & Polypropylene \\
\hline $\begin{array}{l}\text { Biobale (CPR } \\
\text { Aquatics) }\end{array}$ & 825 & Polyvinyl chloride \\
\hline${\text { Bee-cell }(\mathrm{WMT})^{*}}^{*}$ & 653 & Polystyrene \\
\hline Rings (Jaeger) & 356 & Polypropylene \\
\hline Combined packing $^{* *}$ & 1300 & Polyamids \\
\hline $\begin{array}{l}\text { HPCM packing } \\
* *\end{array}$ & 1500 & Polyurethane foam \\
\hline $\begin{array}{l}\text { Notes: }{ }^{*} \text { (Sharvelle et al. 2008). } \\
* * \text { (Mitin } \text { et al. 2014). }\end{array}$ & & \\
\end{tabular}

Pine cones do not have such a large surface contact. At the same time, however, they are a natural material available at no cost unlike the expensive highly porous materials mentioned above.

Table 6 below provides a comprehensive assessment for comparison of organic material packings since not all of the organic material packings (for example, compost and others) can be involved in the geometric comparison.

\section{Results and discussion}

The experiment result is represented by the graph illustrating the relation of the pressure drop in the packing layer to the dummy velocity of air. Such experiments allow us to evaluate the pressure drop on the packing layer that implicitly allows estimating energy costs for carrying out the process using this packing. The pressure drop data help to calculate the specific surface of the packing (see Formula 3).

Figure 6 shows the graph obtained experimentally. 
Table 6. Biofilter media characteristics

\begin{tabular}{llllll}
\hline Parameter & Straw & $\begin{array}{c}\text { Wood } \\
\text { chips }\end{array}$ & $\begin{array}{l}\text { Pine } \\
\text { cone }\end{array}$ & $\begin{array}{c}\text { Com- } \\
\text { post }\end{array}$ & Peat \\
\hline Porosity & Good & Good & Average & Average & Average \\
\hline $\begin{array}{l}\text { Moisture } \\
\text { Capacity }\end{array}$ & Average & Average & Good & Good & Good \\
\hline $\begin{array}{l}\text { Nutrient } \\
\text { Capacity }\end{array}$ & Poor & Average & Average & Good & Good \\
\hline Useful Life & Poor & Average & Good & Good & Good \\
\hline & for & $\begin{array}{l}\text { Good } \\
\text { addi- } \\
\text { tions }\end{array}$ & $\begin{array}{l}\text { Good } \\
\text { aero- } \\
\text { dyna- } \\
\text { mics }\end{array}$ & $\begin{array}{l}\text { Good } \\
\text { microorganism } \\
\text { sources }\end{array}$ & \\
\hline
\end{tabular}

Source: Janni et al. 2011

The graph illustrates the dependence of the pressure drop of the pine cones packing on the dummy air velocity in the apparatus. The following equation (5) was obtained for the packing under consideration:

$$
\Delta P / H=10.18812 \cdot \exp ^{\left(2.10276 \cdot W_{0}\right)},
$$

where: $\Delta P$ - pressure drop in the packing, $\mathrm{Pa} ; H$ - height of the layer, $\mathrm{m} ; W_{0}$ - air flow rate in the empty section of the apparatus, $\mathrm{m} / \mathrm{s}$.

Equation (5) was derived from experimental data with normal confidence $\left(R^{2}=0.94\right)$. During the experiment, we carried out not less than eight measurements of each value of the gas flow velocity.

This formula allows us to calculate the necessary height of the biofilter to take into account during designing. But due to the hydrodynamic properties of the biofiltration process, Equation (5) could be clarified and amended.

Specific attention should be focused on the peculiarities of the hydrodynamic regime of the biofiltration process

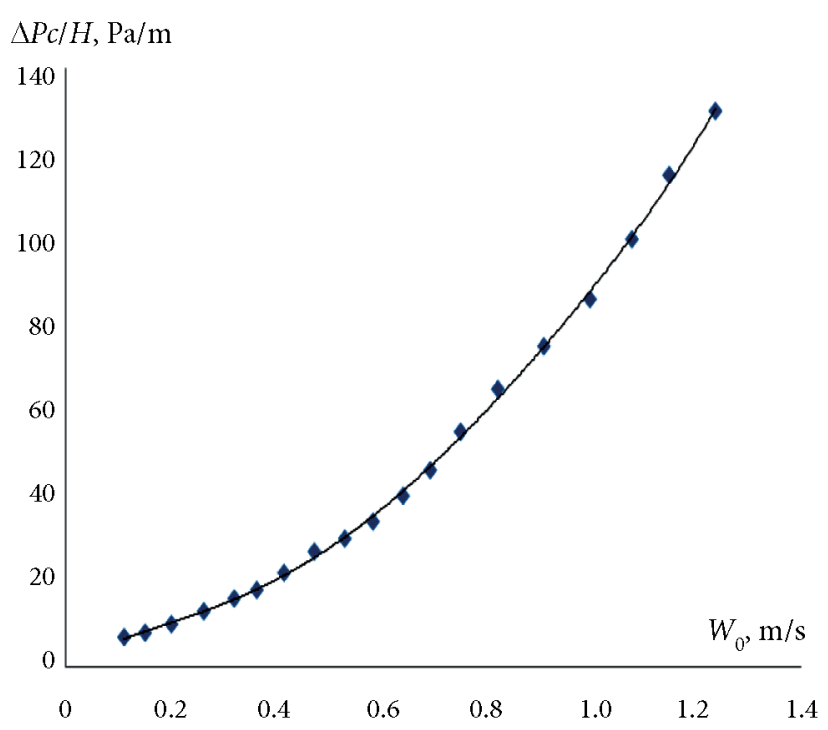

Fig. 6. Dependence of the pressure drop $\Delta P c / H$ on the air velocity $W_{0}$ for the dry packing under test (pine cones) which is described by low air flow rates $\left(W_{0}<1 \mathrm{~m} / \mathrm{s}\right)$ and, accordingly, low Reynolds numbers. Thus, it is possible to extract the boundaries of the air flow regimes: viscous and inertial.

The boundaries of the stream regimes can be determined during the biofiltration process. If the Reynolds number is less than 40 , which is related to the equivalent diameter of the packing, viscous force is dominating and the pressure drop is determined only by the friction in the walls of the flow channels. The biofiltration process could be optimized while determining the exact boundaries of the hydrodynamic regime.

The experimentally obtained graph clearly shows the boundaries of the air flow regime: viscous and inertial.

In Figure 7, the dotted line is a boundary between the viscous and inertial regimes of the air flows for the pine cones packing. Operating speed of the biofiltration process is $0.05-$ $0.5 \mathrm{~m} / \mathrm{s}$. Thus, we can draw a conclusion that the biofiltration process occurs under the viscous air flow regime.

The left part of the dotted line in the graph can be determined by a non-linear equation. This line illustrates the viscous flow regime.

The line above the dotted one is determined by a linear equation. This line represents the inertial air flow regime.

During the biofiltration process, high velocity characterized by the inertial regime is not typical. Therefore, this range can be disregarded. Hence, it is recommended to use the non-linear equation describing the viscous flow regime to perform calculations.

Figure 8 shows a plot of the pressure drop of air velocity for different packings of different content. Despite different geometric characteristics, the general trend is obvious for all the packing types. According to the graph, we can define the boundaries of the viscous and inertial flow regime.

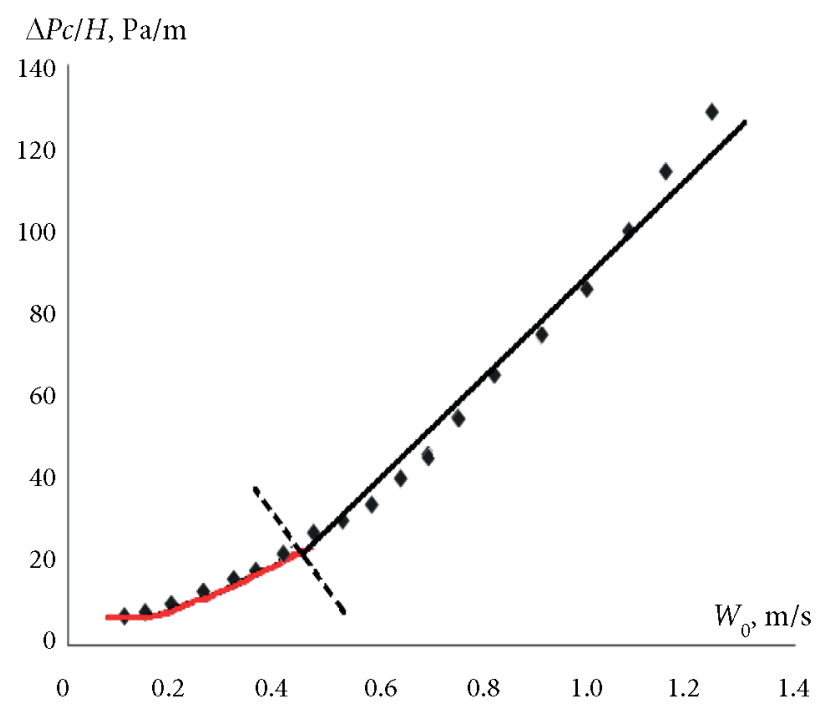

Fig. 7. Dependence of the pressure drop $\Delta P_{c} / H$ on the flow velocity $W_{0}$ for the dry packing under test (pine cones) 


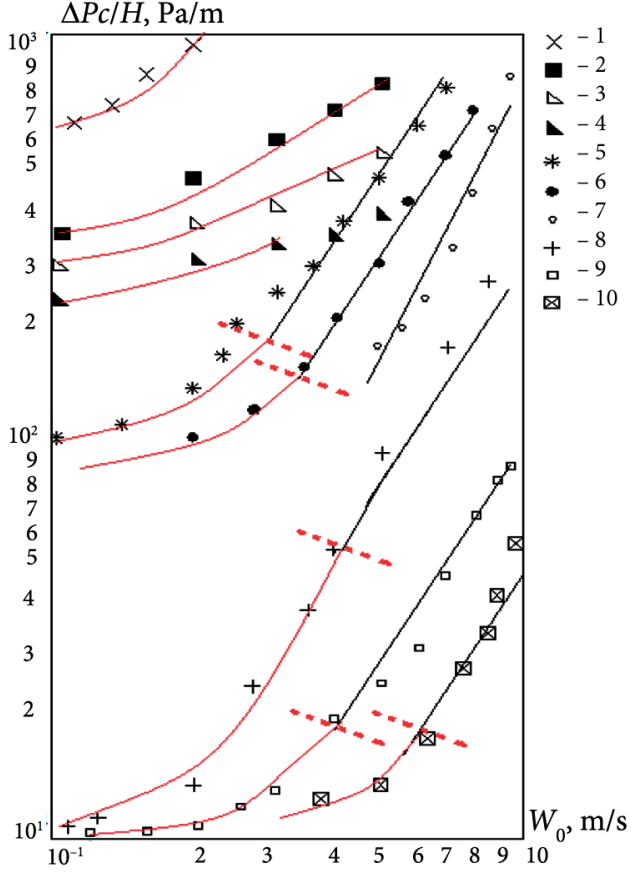

Fig. 8. Dependence of the pressure drop $\Delta \mathrm{P}_{c} / \mathrm{H}$ on the gas velocity $\mathrm{W}_{0}$ per full cross-section of empty apparatus for the following dry packings: 1 - Active carbon SKT2; 2 - mix of wood chips, bark and zeolite granules; 3 - mix of wood chips, bark, granules of zeolite and foam rubber cubes; 4 - mix of wood chips, bark and foam rubber cubes (Pushnov et al. 2012); 5 - Combined packing (Mitin et al. 2014); 6 - Ceramic Raschig rings; 7 - Metal Raschig rings (Pushnov, Kagan 2011); 8 - HPCM packing (Mitin et al. 2014); 9 - pine cones (our experiments); 10 - Mellapak 250Y (Chavez, Guadarrama 2010)

The results of the studies on the hydrodynamic regime allow us to determine the regime boundaries for the biofiltration process with a pine cones packing. The information about different characteristics of the air flow under different velocity is confirmed by other studies (Pushnov et al. 2012) specializing in heat and mass-transfer processes. This allows us to apply mathematical models used in the studies (Pushnov et al. 2012) to the biofiltration process as well.

Figure 8 shows the conventional boundaries between the two flow regimes - viscous and inertial - for different packings. When the air flow rate in a biofilter with a packing of pine cones is more than $0.4 \mathrm{~m} / \mathrm{s}$, then there is the inertial flow regime. For this regime, the dependence between the pressure drop and air flow rate is linear in logarithmic coordinates $\Delta \mathrm{Pc} / \mathrm{H}=\mathrm{f}\left(\mathrm{W}_{0}\right)$ (Kagan et al. 2008). When the air flow rate is less than $0.4 \mathrm{~m} / \mathrm{s}$, then there is the viscous air flow regime which is determined by a nonlinear equation.

From our point of view, additional studies to determine the dependence between the pressure drop and air flow rate for packings 2, 3, 4 as shown in Figure 8 are required since the available information (Pushnov et al. 2012) does not allow us to determine the boundary between the viscous and inertial flow regimes for these packings.
The graph in Figure 8 illustrates that the structured packing Mellapak 250Y has a lesser pressure drop than the tested pine cones packing although the latter has a significantly larger specific surface.

A biofilter with a pine cones packing can be used for purification of flue gases of toluene. In the long term, biofilters with a packing of pine cones will be tested in deodorization of air at tobacco productions.

\section{Conclusions}

1. Pine cones were considered as a natural packing material.

2. This packing has a low aerodynamic resistance (about $80 \mathrm{~Pa} / \mathrm{m}$ at air velocity up to $1 \mathrm{~m} / \mathrm{s}$ ) and a high specific surface of $320 \mathrm{~m}^{2} / \mathrm{m}^{3}$.

3. For this packing, the hydrodynamic regime was determined. This regime corresponds to the operating air rates in biofilters. The hydrodynamic boundary regime is within the air velocity of $0.4 \mathrm{~m} / \mathrm{s}$.

4. Said packing material serves not only as a surface but also as a proper media for the microorganisms' activity. Also, pine cones are well wettable. It is an easily accessible (implying no production costs) and environmentally friendly material.

\section{Acknowledgements}

Special thanks to Konstantin Mitin, Asya Buyanova, Vadim Pilipenko, Aleksandr Gorodilov, Ivan Serenov and Ivan Sidelnikov for assistance in the experiments.

\section{References}

Baltrenas, P.; Zagorskis, A. 2010. Investigation into the air treatment efficiency of biofilters of different structures, Journal of Environmental Engineering and Landscape Management 18(1): 23-31. http://dx.doi.org/10.3846/jeelm.2010.03

Baltrenas, P.; Vaiskunaite, R.; Spakauskas, V. 2004a. Experimental study and mathematical modelling of biofilter aerodynamic resistance, Journal of Environmental Engineering and Landscape Management 12(3): 79-84.

Baltrenas, P.; Vaiskunaite, R. 2004. Issledovanie biofiltra s biologicheski aktivnim sloem iz sosnovoy kori pri ochistke vozduha ot letuchih uglevodorodov [Investigation of the biofilter with a biologically active layer of pine bark in the purification of air from volatile hydrocarbons], Chemical and Petroleum Engineering 7: 29-31.

Baltrenas, P.; Zigmonetiene, A.; Vaiskunaite, R. 2004b. Oro valymo biotechnologijos [Biotechnology of air purification]. Vilnius: Technika. ISBN 9986-05-787-6.

Chavez, R.; Guadarrama, J. 2010. Comparison of structured packings in $\mathrm{CO}_{2}$ absorber with chemical reactions, Chemical Engineering Transactions 21: 577-582.

Chen, L. S.; Hoff, J. 2009. Mitigating odors from agricultural facilities: a review of literature concerning biofilters, American Society of Agricultural and Biological Engineers 25(5): 751-766. 
Delhomenie, M.; Heitz, M. 2005. Biofiltration of air: a review, Critical Reviews Biotechnology 25: 53-72. http://dx.doi.org/10.1080/07388550590935814

Devinny, J. S.; Deshusses, M. A.; Webster, T. S. 1999. Biofiltration for air pollution control. Boca Raton (Fla): Lewis Publishers.

Dorado, A. D.; Lafuente, J.; Gabriel, D.; Gamisans, X. 2010. The role of water in the performance of biofilters: parameterization of pressure drop and sorption capacities for common packing materials, Journal of Hazardous Materials 180: 693702. http://dx.doi.org/10.1016/j.jhazmat.2010.04.093

Dumont, E.; Andres, Y.; Le Cloirec, P.; Gaudin, F. 2008. Evaluation of a new packing material for $\mathrm{H}_{2} \mathrm{~S}$ removed by biofiltration, Biochemical Engineering Journal 42: 120-127. http://dx.doi.org/10.1016/j.bej.2008.06.012

FS 17.2.4.06-90 Nature protection. Atmosphere. Methods for determination of velocity and flow rate of gas-and-dust streams from stationary sources of pollution. 2013.

FS 17.2.4.07-90 Environment protection. Atmosphere. Methods for determination of pressure and temperature of gas-and-dust streams from stationary sources of pollution. 2013.

FS 17299 Technical ethyl alcohol. Specifications. 1999.

FS 28498 Liquid-in-glass thermometers. General technical requirements. Methods of tests. 1998.

FS 9933 Liquid manometers. Specifications. 1993.

Janni, K. A.; Nicolai, R. K.; Hoff, S.; Stenglein, R. M. 2011. Air quality education in animal agriculture: biofilters for odor and air pollution mitigation in animal agriculture. Agricultural and Biosystems Engineering Extension and Outreach publications. Iowa State University.

Kagan, A.; Laptev, A.; Pushnov, A.; Farahov, M. 2013. Contact packings of industrial heat and mass transfer apparatuses. Kazan: Otechestvo. ISBN 978-5-9222-0664-8.

Kagan, A.; Yudina, L.; Pushnov, A. 2008. Gidravlicheskoe soprotivlenie i udelnia poverhnost nereguliarnich nasadok [Hydraulic resistance and surface area of irregular attachments], Russian Chemical Industry 85(3): 147-150.

Kumar, T. P.; Rahul; Kumar, M. A.; Chandrajit, B. 2011. Biofiltration of Volatile Organic Compounds (VOCs) - an overview, Research Journal of Chemical Sciences 1(8): 83-92.
Mackowiak, J. 2010. Fluid dynamics of packed columns for gas/ liquid and liquid/liquid systems. Berlin: Springer. ISBN 9783-540-88780-5. http://dx.doi.org/10.1007/b98397

Mitin, A.; Nikolajkina, N.; Pushnov, A. 2014. Nasadki dlia gazoochistnih biofiltrov [Packing for gas cleaning biofilters], Ekologia i promislennost Rossii 5: 2-6.

Mitin, A.; Nikolajkina, N.; Zagustina, N.; Pushnov, A. 2012. Izuchenie rabochih characteristic combinirovannoi nasadki dlia processov ochistki gazov v biofiltrah [Studying the performance of the combined packing for gas cleaning processes in biofilters], Izvestia MGTU "MAMI" 4(2): 92-96.

Pushnov, A.; Baltrenas, P.; Kagan, A.; Zagorskis, A. 2012. Aerodinamica vozduhoochistnich ustroistv s zernistim sloem [The aerodynamics air cleaning devices with granular layer]. Vilnius: Technika. ISBN 978-9955-28-643-1.

Pushnov, A.; Kagan, A. 2011. Structura i gidrodinamica kolonnih apparatov s nasadkoi [Structure and hydrodynamics of packed columns]. Spb: Izdatelstvo politechnicheskogo universiteta.

Ryu, H. W.; Kim, S. J.; Cho, K. S. 2010. Comparative studies on toluene removal and pressure drop in biofilters using different packing materials, Journal of Environmental Biology 31: 315-318.

Sharvelle, S.; Arabi, M.; McLamore, E.; Katherine Banks, M. 2008. Model development for biotrickling filter treatment of graywater simulant and waste gas, Journal of Environmental Engineering 134(10): 813-825. http://dx.doi.org/10.1061/ (ASCE)0733-9372(2008)134:10(813)

Vaiskunaite, R. 2004. Research and application of the biofilter with activated pine bark charge for air purification. Vilnius: Technika.

Vedova, L. 2008. Biofiltration of industrial waste gases in tricklebed bioreactors. Case study: trichloroethylene removal. Scuola di Dottorato in Ingegneria Industriale Indirizzo Ingegneria Chimica XX Ciclo: PhD Thesis. Gennaio.

Veprickiy, A.; Zhukov, V.; Zagustina, N. 2012. Application of biological purification technology for gas emissions alphaset-process, in IV mezdunarodniy kongress "Cvetnie metallic" [Fourth International Congress of non-ferrous metals], 05 September 2012, Krasnoyarsk, Russia.

Zagorskis, A. 2009. Research and design of low capacity air treatment biofilters. Vilnius: Technika.

Aleksandr MITIN. Department of Engineering Ecology of Municipal Services, Moscow State University of Mechanical Engineering. PhD student. Processes and devices of chemical technology. Research interests: Biological air purification, engineering ecology.

Natalya NIKOLAJKINA. Department of Engineering Ecology of Municipal Services, Moscow State University of Mechanical Engineering. PhD in Technical Sciences. Professor of the Department of Engineering Ecology of Municipal Services. Research interests: Processes and devices of environmental protection. Publications: about 200 publications, including 2 textbooks (recommended by the Ministry of Education as a textbook, 8 publications), 39 teaching aids, 15 patents of the Russian Federation. Honorary Worker of Higher Professional Education of Russia. Member of the International Academy for Sciences Ecology and Life (IAELPS).

Aleksandr PUSHNOV. Department of Green Manufacturing Technology, Moscow State University of Mechanical Engineering. PhD in Technical Sciences. Research interests: Aerodynamics of fixed granular bed devices, regular and random packings for heat and mass transfer processes, cooling towers. Publications: Author of over 110 scientific publications and patents. 